\title{
The plain packaging of tobacco products and its recognition by the WTO as a legitimate policy measure for the protection of public health
}

A embalagem genérica de produtos fumígenos derivados do tabaco e seu reconhecimento pela OMC como uma medida de política pública legítima para a proteção da saúde

El empaquetado neutro de tabaco y su reconocimiento por parte de la OMC como una medida política legítima para la protección de la salud pública

Wolney da Cunha Soares Junior ${ }^{1,2}$

\begin{abstract}
Introduction: the adoption by the WTO DSB of the Panel Reports that resolved the disputes against the Australian tobacco plain packaging scheme unveil important aspects of international health law intertwined with international trade law. Objectives: this paper aims at understanding the concept of plain packaging and the scope of the WTO decision for countries envisaging the adoption of similar measures in policymaking. The research questions are descriptive and encompass how the position expressed by the WTO DSB affects the WHO FCTC and what legal reasoning the referred decision used. Methodology: a historical method is employed to identify the origins of plain packaging and the main concerns and challenges surrounding it, whilst a discursive analysis of the Panel Reports allows an interpretation of its basic principles and possible implications for public health policies. Results and discussion: from a microeconomic policy analysis, the standardization of tobacco packets is a reasonable regulatory approach at a government's disposal for addressing welfare losses due to externalities and internalities. Although there is no consensus on the empirical evidence supporting plain packaging, its assessment by the WTO Panel played a vital role in the decision rendered, notably with respect to Article 2.2 of the TBT Agreement and Article 20 of the TRIPS Agreement. Conclusion: Honduras and Dominican Republic have appealed and consequently a final ruling is still pending. Nonetheless, the decision is so far a recognition under WTO law of a State's regulatory autonomy to implement the necessary measures on behalf of public health.
\end{abstract}

Keywords: Public health policy. Tobacco. Product packaging.

\section{Resumo}

Introdução: a decisão da OMC sobre embalagens genéricas de produtos fumígenos revela aspectos relevantes da relação entre o direito internacional da saúde com o direito internacional do comércio. Objetivos: este artigo analisa o conceito da embalagem genérica e o alcance da decisão da OMC para países que pretendem debater a adoção de medidas semelhantes. As perguntas de pesquisa são descritivas e perquirem a forma como a decisão da OMC se relaciona com a CQCT/OMS e a fundamentação jurídica em que ela se baseou. Metodologia: um método histórico é empregado para identificar as origens da embalagem

\footnotetext{
${ }^{1}$ Master of Public Policy candidate, Hertie School of Governance, Berlin, Germany; federal attorney, Attorney General's Office for the Federal Agencies, Brasília, Federal District, Brazil. https://orcid.org/0000-0001-5517-0689. E-mail: wolney_jr@yahoo.com.br

2 The views expressed in this article are the personal views of the author and may not be understood or quoted as being made on behalf of or reflecting the position of the organization that the author works for.
} 
genérica e seus principais embates, enquanto uma análise discursiva da decisão da OMC permite a interpretação de seus princípios básicos e suas implicações na formulação de políticas de saúde. Resultados e discussão: uma análise econômica indica que a embalagem genérica é uma alternativa regulatória razoável à disposição dos Estados para tentarem lidar com as perdas de bem-estar resultantes de externalidades e internalidades. Embora existam discordâncias quanto à efetividade das embalagens genéricas, os dados levados à OMC tiveram um papel importante na tomada da decisão, em particular na aplicação do artigo 2.2 do Acordo TBT e do artigo 20 do Acordo TRIPS. Conclusão: Honduras e República Dominicana recorreram. Um julgamento final ainda é aguardado, mas a atual decisão representa, à luz do direito internacional do comércio, um reconhecimento pela OMC da soberania e autonomia dos Estados para adotarem as medidas regulatórias baseadas em evidências que entendam necessárias para a tutela da saúde pública.

Palavras-chave: Política pública de saúde. Tabaco. Embalagem de produtos.

\section{Resumen}

Introducción: la adopción del OSD de la OMC de los informes del Panel que resolvió las disputas contra el esquema de empaquetado neutro de tabaco en Australia revela aspectos importantes del derecho internacional de la salud entrelazados con derecho comercial internacional. Objetivos: comprender el concepto de empaquetado genérico y el alcance de la decisión de la OMC para los países que pretenden debatir la adopción de medidas similares. Las preguntas de investigación son descriptivas y abarcan cómo la posición expresada por la OMC afecta el CMCT/OMS y la base legal de la decisión. Metodología: un método histórico sirve para identificar los orígenes de los paquetes estandarizados, mientras que un análisis discursivo de la decisión de la OMC permite la interpretación de sus principios básicos y sus implicaciones para la formulación de políticas de salud. Resultados y discusión: la estandarización de los paquetes de tabaco es un enfoque regulatorio a disposición del gobierno para abordar las afectaciones al bienestar social causadas por externalidades e internalidades. Aunque no hay consenso sobre la evidencia empírica que respalda el empaquetado neutro, su evaluación por el Panel de la OMC desempeñó un papel importante en la decisión emitida, en particular con respecto al Artículo 2.2 del Acuerdo OTC y el Artículo 20 de Acuerdo sobre los ADPIC. Conclusión: aunque Honduras y República Dominicana han apelado y, en consecuencia, aún está pendiente la resolución final; la decisión es hasta ahora es un reconocimiento bajo la ley de la OMC de la autonomía reguladora de un Estado.

Palavras clave: Política de salud pública. Tabaco. Embalaje de produtos.

\section{Introduction}

On 28 June 2018, the World Trade Organization (WTO) made officially known the resolution of an intricate legal challenge raised by Cuba, Dominican Republic, Honduras and Indonesia ${ }^{3}$ against Australia's tobacco plain (standardized) package scheme. Later on, the WTO Dispute Settlement Body (DSB) adopted the Panel Reports (1) that had previously circulated rejecting the alleged violations of the General Agreement on Tariffs and Trade

\footnotetext{
${ }^{3}$ Initially Ukraine had also initiated an identical dispute, but it decided to withdraw its claim before the conclusion of the Panel Reports.
} 
(GATT), the Agreement on Technical Barriers to Trade (TBT Agreement) and the Agreement on Trade-Related Aspects of Intellectual Property Rights (TRIPS Agreement).

Although Honduras and the Dominican Republic have appealed and consequently a final ruling is still pending, the aforementioned WTO disputes unveil important aspects of international trade law intertwined with international health law that deserve a closer examination. By clarifying that plain packages do not represent technical barriers under TBT Agreement nor restrictions to trademarks under TRIPS Agreement, the WTO decision also reverberated in the applicability of the World Health Organization (WHO) Framework Convention on Tobacco Control (FCTC), indicating that there is no conflict of laws. Moreover, the significance of the matter is perceivable by the fact that the referred understanding of the DSB dispelled many of the doubts raised in the international scenario concerning the pioneering implementation by Australia of tobacco plain packaging, albeit provisory considering the appeals lodged are still awaiting a decision. Indeed, the upholding of such understanding under WTO law may contribute in the coming years towards a worldwide employment of similar policies in an increasing number of countries whose improvements in domestic policymaking regarding tobacco control ${ }^{4}$ and health protection sometimes may simply not occur due to the inaccurate beliefs in non-existent inconsistencies with their multiple international obligations.

As stated by the WHO, in addition to Australia "France, Hungary, Ireland, New Zealand, Norway and the United Kingdom of Great Britain and Northern Ireland have implemented plain packaging laws" (2), "Uruguay also published plain packaging laws" and "Burkina Faso, Canada, Georgia, Romania, Slovenia and Thailand have passed enabling laws" (2).

Despite the binding effects of the Panel and Appellate Body Reports adopted by the DSB being limited to the respective parties to those particular disputes brought to the WTO, it is widely acknowledged that they represent a source of international law. More precisely, the adopted Panel and Appellate Body Reports serve notably as subsidiary means of determination of rules of law and, therefore, fairly create expectations among other WTO members of how occasional upcoming disputes alike might be settled in the future (3).

All the above facts and relevant legal implications likely explain why there were so many international actors interested in participating in the panel proceedings as either amici curiae ${ }^{5}$

\footnotetext{
${ }^{4}$ Tobacco control means "a range of supply, demand and harm reduction strategies that aim to improve the health of a population by eliminating or reducing their consumption of tobacco products and exposure to tobacco smoke" (4).

5 The WTO Panel received amicus curiae submissions from World Health Organization (WHO); WHO Framework
} 
or third parties ${ }^{6}$. The former under Appellate Body case law, whose acceptance of the "friend of the court" briefs is not free from harsh criticisms by many WTO members (4), and the latter based on Article 10 of the understanding on rules and procedures governing the settlement of disputes (5):

\begin{abstract}
Article 10
$[\ldots]$

2. Any Member having a substantial interest in a matter before a panel and having notified its interest to the DSB (referred to in this Understanding as a 'third party') shall have an opportunity to be heard by the panel and to make written submissions to the panel. These submissions shall also be given to the parties to the dispute and shall be reflected in the panel report. (6)
\end{abstract}

The goal of this paper is to analyze the concept of plain packaging, its objectives, and the scope of the WTO decision for countries envisaging the adoption of similar measures in policymaking. Thus, the research questions are descriptive and encompass how the position expressed by the WTO DSB affects the WHO FCTC and what legal reasoning the referred Panel Reports used. Accordingly, this paper consists of 3 (three) sections. It first examines the concept of plain packaging under the WHO FCTC and provides an economic analysis of plain packaging as a regulatory response to externalities and internalities. In the second section, it looks over the varied legal disputes involving plain packaging until a WTO panel

Convention on Tobacco Control Secretariat; Emergency Committee for American Trade; National Association of Manufacturers of the United States; National Foreign Trade Council; Paperboard Packaging Council; Printing Industries of America; Independent Packaging Association; United States Chamber of Commerce; and United States Council for International Business; Emergency Committee for American Trade, National Association of Manufacturers of the United States, National Foreign Trade Council, Paperboard Packaging Council, Printing Industries of America, Independent Packaging Association, United States Chamber of Commerce, and United States Council for International Business; Associação Brasileira da Propriedade Intelectual; American Chamber of Commerce in the Netherlands; Federation of Philippine Industries; Confederação Nacional da Indústria (Brazil); Federation of Attica and Piraeus Industries; Cámara Nacional de Comercio y Servicios del Uruguay; Federação das Indústrias do Estado da Bahia (Brazil); Japan Business Federation; Association of South-East Asian Nations (ASEAN) Intellectual Property Association; Institute of Public Affairs; Cámara de Industria de Guatemala; Trade-related IPR Protection Association; Indonesian Chamber of Commerce and Industry; Montenegrin Employers Federation; Taxpayers Association of Europe; International Trademark Association; Australian Retailers Association; Japan Intellectual Property Association; Association of European Businesses in Russia, American Chamber of Commerce in Russia, and RusBrand; International Tobacco Growers' Association; Patent and Trademark Attorneys Association - Turkey; Aegean Exporters Association; European Association of Trade Mark Owners (MARQUES); United States Chamber of Commerce; EU-ASEAN Business Council, EU-Malaysia Chamber of Commerce and Industry, European Chamber of Commerce in Singapore, European Chamber of Commerce of the Philippines, European Chamber of Commerce and Industry in Lao PDR, and European Association of Business and Commerce in Thailand; American Chamber of Commerce in Thailand; Romanian Small and Medium Retailers Association; Association of Trademarks and Design Rights Practitioners; Canadian Manufacturers and Exporters; Federation of Korean Industries; Polish Chamber of Trade; Union des Fabricants; Healthy Caribbean Coalition; Union for International Cancer Control; Cancer Council Australia; and World Health Organization and WHO Framework Convention on Tobacco Control Secretariat; Russian Union of Industrialists and Entrepreneurs; Graphic Association Denmark; American Chamber Mexico; Malaysian International Chamber of Commerce and Industry; and Confederation of Danish Industry. (7)

6 The European Union, Argentina, Brazil, Canada, Chile, China, Ecuador, Guatemala, India, Japan, the Republic of Korea, Malawi, Malaysia, Mexico, New Zealand, Nicaragua, Nigeria, Norway, Oman, Peru, the Philippines, the Russian Federation, Singapore, Chinese Taipei, Thailand, Turkey, Ukraine, the United States, Uruguay and Zimbabwe notified their interest to the DSB. 
was established. Thereafter, it analyzes the WTO decision on Article 2.2 of the TBT Agreement (technical barriers to trade) and Article 20 of the TRIPS Agreement (restrictions to trademarks). The paper concludes that the WTO decision strengthens the provisions of the WHO FCTC by acknowledging States' regulatory autonomy to discuss the adoption of plain packaging of tobacco products since there would not be an impediment from the point of view of international trade law.

\section{Methodology}

The proposed research has a qualitative nature. The data collection involves miscellaneous documentary records such as international treaties, decisions from various fora, policy documents and academic writings. A historical method is employed in an attempt to identify the origins of plain packaging and the main concerns and challenges surrounding it, whilst a discursive analysis of the Panel Reports is used to interpret its basic principles and its possible implications for the elaboration of public health policies.

\section{Plain packaging of tobacco products as a policy measure for the protection of public health}

The definition and objectives of tobacco plain packaging in concordance with the WHO FCTC

The WHO FCTC was signed in 2003 as a response to a tobacco epidemic estimated in causing worldwide over 7 million deaths a year (6). It is an evidence-based global public health treaty with provisions on various supply-side and demand-side tobacco control measures. The strategies, plans and programs, conceived to be carried out in conjunction for the achievement of better results, include the regulation of product disclosure, tobacco advertising, promotion and sponsorship; and measures concerning taxation, the packaging and labelling of tobacco products, public awareness, illicit trade in tobacco products, and sales to and by minors.

In this context, the guidelines for the implementation of demand-side reduction measures prescribed by Articles 11 and 13 of the WHO FCTC provide jointly a definition and core elements for plain packaging. Accordingly, plain packaging involves "measures to restrict or prohibit the use of logos, colours, brand images or promotional information on packaging other than brand names and product names displayed in a standard colour and 
font style" (7). Furthermore, plain packaging is restricted to "black and white or two other contrasting colours, as prescribed by national authorities." (7)

It must contain

nothing other than a brand name, a product name and/or manufacturer's name, contact details and the quantity of product in the packaging, without any logos or other features apart from health warnings, tax stamps and other government-mandated information or markings; prescribed font style and size; and standardized shape, size and materials. There should be no advertising or promotion inside or attached to the package or on individual cigarettes or other tobacco products. (7)

It is noteworthy that the WHO admittedly recognizes the existence of a variation in the implementation of standardized packaging among different jurisdictions depending on, for example, particular policy choices made by each country in the design of the intended measures. Nevertheless, the adoption of plain packaging of tobacco products seeks overall the same purposes, namely the reduction in their attractiveness and the elimination on the effects of tobacco packaging as a form of advertising and promotion. In addition, it serves as well as an attempt to address package design techniques that suggest some products are less harmful than others, reducing the chance of consumers being somehow misled about the negative effects of smoking, while at the same time increasing the noticeability and effectiveness of health warnings (8). Even in countries where tobacco advertising has been almost entirely prohibited, the tobacco companies may still try to design their packages as a last resource to send a variety of distinguishing information and attractive messages to their potential consumers, such as the use of distinct colours or pack shapes to relativize the harmfulness of certain tobacco products. (9)

Thereon, the WHO FCTC guidelines adopted in the Conference of the Parties (COP) propose the adoption of plain packaging ${ }^{7}$ among other policy recommendations as best practices and standards to help governments in the treaty-implementation process, although the treaty itself does not impose this obligation on its current 181 parties (10).

\footnotetext{
${ }^{7}$ The guidelines for the implementation of Articles 11 and 13 of WHO FCTC state "Parties should consider adopting" plain packaging (7).
} 
Economic analysis of plain packaging as an adequate regulatory response to externalities and internalities

An externality "occurs whenever the actions of one party make another party worse or better off, yet the first party neither bears the costs nor receives the benefits of doing so" (11). Thus, the identification of externalities provides a solid economic justification for the intervention of governments in the market, which may appear in different forms, particularly through taxation or regulation. A good example of the latter is the imposition of plain packaging.

In this regard, with Gruber's remarks ("externalities do not arise solely from the production side of a market") in consideration (11), smoking is at the same time a negative production and consumption externality. Not only does tobacco production reduce the wellbeing of its final consumers, but also generates further negative effects on others through an individual's consumption. In both cases, there is no payment of compensation to those who face a welfare loss.

These ideas are in conformity with a traditional economic approach, which notoriously advocates that only burdens imposed on other people should lead to government intervention and provide its strict boundaries out of which the free market ought to prevail. Surely this reasoning of externalities can be considered enough for the adoption of a variety of policy tools, including plain packaging; however, should policymaking really refrain from dealing with internalities, meaning an individual's short-term behavior that reveals itself suboptimal in a long-term perspective? This is a controversial issue, and an affirmative answer to the posed question would imply that any harm a person (smoker) causes to himself/herself is no reason for state action because the person involved has voluntarily accounted for it in his/her own decision whose consequences he/she shall bear alone. After all, this assumes a perfect utility maximization model that exclusively encompasses fully rational trade-off choices made by adult smokers, and it consequently neglects some existing imperfect real-world factors. It is highly questionable whether public health policies should merely ignore decisions to smoke made by adolescents who rashly and incorrectly evaluate the risks of their initiation of an addictive behavior in terms of current benefits (immediate pleasure) and future costs (life shortening). Another example is the inability of many adults to quit smoking strictly due to self-control limitations. These situations illustrate how under certain circumstances, presentbiased preferences result in serious inter-temporal problems that should not be ignored by 
public authorities. Hence, it is arguable that a plain packaging scheme better suits a modern economic approach that equally considers internalities, namely self-inflicted smoking damages, because it avoids potential misleading marketing strategies that stimulate some economic irrationalities (time-inconsistent behaviors) and simultaneously still highlights, and enhances the effects of health warnings that give important information about the health hazards of smoking.

Having said that, is there empirical evidence on post-implementation outcomes of plain packaging with health warnings or is it purely a libertarian paternalistic intervention that is completely ineffective for achieving the supposed objectives it declares to pursue?

According to the World Health Organization (8) there is a "large body of empirical evidence in the form of experimental studies, surveys and focus group studies" providing "strong evidence to justify the introduction of plain packaging and to support the conclusion that the policy is apt to achieve the objectives identified" (8). On top of that, since the introduction of plain packaging, the Australian government has observed the following figures that demonstrate a decline in the use of, and exposure to tobacco products:

a) The National Drug Strategy Household Survey for 2013 showed a reduction in the prevalence of daily smokers aged 14 years or over to $12.8 \%$ in 2013 , compared with $15.1 \%$ in 2010 .

b) The Australian Secondary Students' Alcohol and Drug survey found that in 2014 only $5.1 \%$ of $12-17$ year olds are current smokers, compared with $6.7 \%$ in 2011.

c) In the National Health Survey rates of daily smoking among adults (18 years and older) have continued to drop, to $14.5 \%$ in $2014-15$, compared with $16.1 \%$ in 2011-12 and 22.4\% in 2001. (8)

Nevertheless, there is no consensus on this matter and a vigorous debate underpinned the WTO disputes as the following excerpts from the Panel Reports illustrate (1):

7.433. Honduras argues that empirical evidence of the actual effect of a measure on behaviour is the best evidence against which to test whether the architecture, structure and design of the measure is apt to contribute to the objective. Reliable and probative empirical evidence of the lack of actual impact of the measure more than two and a half years after its introduction is available and must be given primacy in the analysis. It is not valid for Australia to focus only on theories when there are sufficient facts to assess the impact of the measures.

$[\ldots]$

7.438. The Dominican Republic observes that the relative weight ascribed by a panel to evidence regarding a measure's structure and design, on one hand, 
and its expected or actual operation, or application, on the other, is necessarily case-specific and influenced by variables including the evidence available, the relevance of the evidence, and the nature of the claims and arguments of the parties. Evidence of actual operation may reveal that a measure's design and structure are misconceived, or are not operating as expected, and are thus not probative of whether the measure contributes to its objective. The Dominican Republic argues that, at this stage, evidence of actual operation is far more valuable than mere expectations. Real-word empirical data, which is not opinion-based or predictive, permits an objective assessment of the actual behavioural effects of changing the appearance of tobacco products and their packaging, and is the most reliable and credible evidence available to the Panel to assess the contribution these measures make to achieving their objective. With close to three years' worth of data available at the time of its submission, the Dominican Republic argues that there is no evidence that the TPP measures are having statistically significant effects on prevalence or consumption. A survey conducted by Australia designed to evaluate the actual operation of the TPP measures after implementation also reveals that, 'aside from certain obvious changes in pack appeal and the noticeability of health warnings that more-than-doubled in size', there is a consistent lack of evidence of changes in the so-called antecedents to smoking behaviour. Further, the 'rather limited impact of the policies that we have seen to date will tend to weaken over time'. Thus, the TPP measures have changed neither the antecedents of smoking behaviour nor smoking behaviour itself. In the Dominican Republic's view, the reality of the actual operation is that the TPP measures 'have not lived up to the expectations of either tobacco control researchers or the Australian government'.

7.439. The TPP measures cannot, the Dominican Republic argues, continue to be justified by short-term research-based predictions that have failed to materialize over an extended period. Australia's assertion that the impact of tobacco plain packaging on smoking rates will be most pronounced in the long term must be supported by robust evidence, and cannot be a matter of speculation.

$[\ldots]$

7.441. Cuba also argues that Australia's rationale for adopting the TPP measures was flawed, thus revealing why the measures have been ineffective. The studies that Australia relies upon do not provide a sound basis for concluding that the TPP measures will reduce tobacco use. None of the studies measure actual tobacco consumption. They utilise research designs which leave considerable doubts about the reliability of any conclusions reached, and were implemented in a manner that gives rise to further methodological concerns. Further, research regarding the key determinants of initiation, cessation and relapse indicates that tobacco packaging is not a material factor.

[...]

7.446. Indonesia notes that the Appellate Body has counselled that the contribution of a measure to its objective can be demonstrated quantitatively or qualitatively, and can involve (i) the assessment of evidence or data, pertaining to the past or the present; as well as (ii) quantitative projections in the future, or qualitative reasoning based on a set of hypotheses that are tested and supported by sufficient evidence.

$[\ldots]$ 
7.451. Australia argues that 'TPP fulfils its objectives' by way of a 'mediational' model, or 'causal chain', whereby the TPP measures improve public health by impacting the three mechanisms identified in the TPP Act. There is 'strong empirical evidence' that each of the mechanisms will contribute to Australia's overall objective of protecting human health. Namely, plain packaging decreases the appeal of tobacco products by (i) reducing the attractiveness of tobacco packaging; (ii) reducing positive perceptions of taste; and (iii) reducing positive perceptions of smokers. Plain packaging also increases the effectiveness of health warnings by minimizing distractions of pack design and elements that suppress risk perception, as indicated by studies demonstrating (a) increases in visual attention paid to the warnings; and (b) increases in health warning recall and perceptions about the warnings' believability and seriousness. Pack standardization also limits the ability of the pack to mislead by preventing the use of descriptors, packaging design, colour, and structural innovation to mislead consumers about the harmfulness of tobacco products. Both directly and via each mechanism, the TPP measures affect consumer intentions and behaviour with respect to smoking.

7.452. Australia adds that the evidence supporting tobacco plain packaging is extensive, comprehensive, and reliable, and the complainants' critiques fail to consider its 'overwhelming weight' and 'convergent nature'. The complainants instead exaggerate the studies' limitations and ignore their strengths, among other errors. The most appropriate approach to discerning the effects of the TPP measures in the early stages of its introduction was to rely upon experiments and surveys which consider drivers of choice, attitudes and, ultimately, the elicitation of behavioural intentions, one of the strongest predictors of future behaviour. The complainants' dismissal of this evidence is mistaken, as non-behavioural variables are commonly relied on in consumer, psychology, and marketing research journals and textbooks, and are considered strong predictors of behaviour in tobacco control. Further, empirical evidence demonstrates the effect of the TPP measures on smokingrelated behaviour, as the complainants necessarily concede as a consequence of their argument that the TPP measures have reduced consumers' willingness to pay for certain tobacco products. (1)

Despite the WTO's acknowledgment of the methodological difficulties in assessing solely the actual impact of plain packaging measures on each possible positive related consumer behavior from the data at its disposal, the Panel's overall conclusions about the effects of the standardization of tobacco packets still favored Australia's position. In this manner, the Panel referred to an understanding of the Appellate Body to confirm that the comprehension of plain packaging measures should be found in a broader policy context, which is precisely how all measures prescribed by the WHO FCTC should be seen. Thus, in combination with other tobacco-control measures kept by Australia, plain packaging contributed for reducing the use of, and exposure to tobacco products and in turn undeniably have an impact on smoking behaviors: 
7.981. In this respect, the observations of the Appellate Body on the challenges of isolating the contribution of a measure taken in the context of a comprehensive policy are especially pertinent:

We recognize that certain complex public health or environmental problems may be tackled only with a comprehensive policy comprising a multiplicity of interacting measures. In the short-term, it may prove difficult to isolate the contribution to public health or environmental objectives of one specific measure from those attributable to the other measures that are part of the same comprehensive policy. Moreover, the results obtained from certain actions-for instance, measures adopted in order to attenuate global warming and climate change, or certain preventive actions to reduce the incidence of diseases that may manifest themselves only after a certain period of timecan only be evaluated with the benefit of time.

7.982. We also note the observations of the Appellate Body concerning the type of the evidence that may be pertinent, in such situations, to establish that the measure at issue contributes to the protection of public health or environmental objectives pursued, including 'evidence or data, pertaining to the past or the present', as well as 'quantitative projections in the future, or qualitative reasoning based on a set of hypotheses that are tested and supported by sufficient evidence'.

7.983. As discussed above, the TPP measures are intended, by design, to operate in conjunction with a range of other tobacco control measures, including effective GHWs. In this context, it appears to be inevitable that an assessment of actual outcomes would be made in the presence of such other measures, including GHWs, which could be expected to affect at least to some degree the capacity to isolate the effect of plain packaging, as applied in the presence of such GHWs.

7.984. Notwithstanding this constraint, we consider that the evidence before us usefully informs the contribution, as of the time of our assessment, of the TPP measures to Australia's objective of improving public health by reducing the use of, and exposure to, tobacco products. As described above, a range of evidence has been presented in these proceedings, and discussed, that seeks to identify the effects of the TPP measures since their entry into force. As analyzed in detail in Appendices A to D, this evidence relates to each of the proximal outcomes of interest (appeal of tobacco products, effectiveness of GHWs and ability of the pack to mislead consumers about the harmful effects of tobacco products), to certain smoking-related behavioural outcomes, and to actual smoking behaviours (sales and consumption of tobacco products and smoking prevalence).

$[\ldots]$

7.986. The fact that pre-existing downward trends in smoking prevalence and overall sales and consumption of tobacco products have not only continued but accelerated since the implementation of the TPP measures, and that the TPP measures and enlarged GHWs had a negative and statistically significant impact on smoking prevalence and cigarette wholesale sales, is also consistent with the hypothesis that the measures have had an impact on actual smoking behaviours, notwithstanding the fact that some of the targeted behavioural outcomes could be expected to manifest themselves over a longer period of time. We note in this respect the limited evidence before us addressing the relationship between observed proximal outcomes and actual smoking behaviours, which suggests that further analysis will be required in this respect. 
$[\ldots]$

7.1025. Overall, we find that the complainants have not demonstrated that the TPP measures are not apt to make a contribution to Australia's objective of improving public health by reducing the use of, and exposure to, tobacco products. Rather, we find that the evidence before us, taken in its totality, supports the view that the TPP measures, in combination with other tobaccocontrol measures maintained by Australia (including the enlarged GHWs introduced simultaneously with TPP), are apt to, and do in fact, contribute to Australia's objective of reducing the use of, and exposure to, tobacco products. (1)

Taking into account the applicable procedural rules, which rested the burden of proof with the complainants, the Panel delivered its conclusions based on the quantity and quality of evidence available at the time of its analysis, including external reviews of the existing scientific literature:

7.777. In light of the above, we are not persuaded that the complainants have shown that the TPP measures would not be capable of reducing the appeal of tobacco products, and thereby contribute to Australia's objective of improving public health by reducing the use of, and exposure to, tobacco products.

$[\ldots]$

7.868. In light of the above, we are not persuaded that the complainants have demonstrated that the TPP measures would not be capable of increasing the effectiveness of GHWs, and thereby contribute to Australia's objective of improving public health by reducing the use of, and exposure to, tobacco products.

$[\ldots]$

7.927. On the basis of the above, we are not persuaded that the complainants have demonstrated that the TPP measures, by their design, would not be capable of reducing the ability of tobacco packaging to mislead consumers about the harmful effects of smoking. Furthermore, we are not persuaded that any such contribution to reducing the ability of tobacco packaging to mislead consumers about the harmful effects of smoking could add nothing to what can be achieved under Australia's ACL. (1)

In the next sections of analysis this paper will address how exactly this assessment of the evidence presented to the WTO Panel played an important role in its decision, notably with respect to Article 2.2 of the TBT Agreement and Article 20 of the TRIPS Agreement.

\section{The manifold disputes involving plain packaging, the rationalities underlying them and the origins of the WTO Panel}

\section{The proliferation of legal proceedings regarding plain packaging}

In concordance with WHO FCTC, the Australian Parliament passed in 2011 the 
Tobacco Plain Packaging Act, followed by further enacted regulations, that together established new requirements for the sale of tobacco products in that country. In addition to comply with the already existing tobacco control legislation in place in Australia, now such products also had deadlines to be contained in plain dark brown packs, with enlarged frontof-pack graphic health warnings covering $75 \%$ of the surface, and the use of their brand names and their variants had to observe a predetermined font size, type and placement.

It did not take much time for the tobacco industry to oppose the policy novelties under domestic law and an existing bilateral investment treaty (BIT) signed between Australia and Hong Kong $(12,13)$. At the High Court of Australia, British American Tobacco, Imperial Tobacco Australia Limited, Phillip Morris and Japan Tobacco International argued those new measures were unconstitutional because, to put it briefly, they amounted to acquisition of their private property by the Australian government. However, among other reasons it prevailed the understanding that the imposition of controls on the way in which tobacco products could be packaged and marketed are not different from other legislation and regulations that required warning labels, regardless of their size, to be placed on products to prevent or reduce the likelihood of harm (e.g. medicines, poisonous substances and food). Thus, by majority prevailed the conclusion that such a practice could not result in violation of the meaning of property constitutionally protected in Australia. (12)

Moreover, Philip Morris Asia Limited (PM Asia) also initiated an arbitration proceeding under the Hong Kong - Australia BIT signed in 1993 arguing that "by placing extensive limits on the design of cigarette packs these governments had deprived the company of its intellectual property rights and prevented it from freely using its trademarks" (14). Traditionally, a BIT is a legal instrument whose objective is the protection of transnational investors' assets against political risks (e.g. arbitrary expropriation), guaranteeing them a non-discriminatory treatment, if there is any doubt in relation to the fairness and effectiveness of the host State's national legal system and structures (15). However, in the case concerning the 2011 Tobacco Plain Packaging Act, the Tribunal constituted in accordance with the Hong Kong - Australia BIT did not even examine the measures challenged under international trade law because it upheld a preliminary objection involving the inadmissibility of the arbitration and subsequently declared its preclusion from exercising jurisdiction over the dispute. Australia succeeded in demonstrating and convincing the Tribunal that PM Asia rearranged its corporate structure and affairs at a point in time where a dispute was foreseeable with a 
clear objective of raising the protection of the BIT and therefore such maneuver would characterize in practice an abuse of rights. (13)

From the perspective of the numerous international actors with different rationalities and corresponding legal reasoning, Ruse-Kahn (16) synthesize the problem in the following way:

[...] for tobacco companies and other brand owners, it is a matter of protecting their property in form of IP rights and other investments against interference by foreign governments. For tobacco producing countries, it is about guarding domestic industries, their export opportunities, and free trade against 'unnecessary' trade barriers. For Australia and other countries considering similar measures, it is about public health, the right to regulate harmful substances and to protect the human right to health of its citizens against the detrimental effects of smoking. The main actors have at least one international set of rules which they can rely upon to maximize their preferred rationality: IP- and Investment protection, trade liberalization, public health and human rights all find their expression in distinct rules that compete with their own perspective and solutions for recognition and application on the international plane. (16)

Holden and Hawkins (14) and Mirzabegian (13) point out the aspect of the strategies used by the tobacco industry being an attempt to induce a regulatory chilling or chilling effect on the implementation of plain packaging in other countries, notably low and middle-income nations since litigations are burdensome procedures whose considerable costs may work as an inhibiting factor for them. The authors also bring up the fact that differently from the previous disputes depicted above, within the WTO it is not possible the initiation of a procedure directly by corporations. Nonetheless, these corporations support in many ways the complainant countries that end up acting as proxies for their interests against decisions taken in another State's policy-making process in which their stances did not prevail. Then, through the creation of WTO Panels that extend over lengthy years and implicate enormous expenditures of money, the objective in the end would be once more the pursuit of the same chilling effect.

Considering the alleged violations of international trade law raised by Cuba, Dominican Republic, Honduras and Indonesia, the focus of the next topics is the analysis of the WTO Panel Reports concerning particularly Article 2.2 of TBT Agreement and Article 20 of TRIPS Agreement. These articles are among the important legal basis argued in the pending appeals lodged by Honduras and Dominican Republic (17). 


\section{Panel decision on Article 2.2 of the TBT Agreement (technical barriers to trade)}

The complainants claimed that the Australian plain packaging scheme was inconsistent with Article 2.2 because it is "more trade-restrictive than necessary to fulfil a legitimate objective" within the meaning of Article 2.2 of TBT Agreement (18):

Article 2: Preparation, Adoption and Application of Technical Regulations by Central Government Bodies

[...]

2.2 Members shall ensure that technical regulations are not prepared, adopted or applied with a view to or with the effect of creating unnecessary obstacles to international trade. For this purpose, technical regulations shall not be more trade-restrictive than necessary to fulfil a legitimate objective, taking account of the risks non-fulfilment would create. Such legitimate objectives are, inter alia: national security requirements; the prevention of deceptive practices; protection of human health or safety, animal or plant life or health, or the environment. In assessing such risks, relevant elements of consideration are, inter alia: available scientific and technical information, related processing technology or intended end-uses of products. (18)

In this line of reasoning, they enumerated alternative measures that would be, in their view, less trade-restrictive than plain packaging and reasonably available to Australia to achieve its objective of public health protection.

Due to the fact that the specific elements regarding plain packaging in the guidelines for the implementation of the WHO FCTC could not be framed as "relevant international standards" for the purpose of Article 2.5 of TBT Agreement (18):

Article 2: Preparation, Adoption and Application of Technical Regulations by Central Government Bodies

$[\ldots]$

2.5 A Member preparing, adopting or applying a technical regulation which may have a significant effect on trade of other Members shall, upon the request of another Member, explain the justification for that technical regulation in terms of the provisions of paragraphs 2 to 4 . Whenever a technical regulation is prepared, adopted or applied for one of the legitimate objectives explicitly mentioned in paragraph 2 , and is in accordance with relevant international standards, it shall be rebuttably presumed not to create an unnecessary obstacle to international trade. (18)

The Panel refuted the Australian plain packaging measures were "rebuttably presumed not to create an unnecessary obstacle to international trade" (1).

Following the Appellate Body case law, the WTO Panel in Australia - Tobacco Plain Packaging clarified that the assessment of the consistency of a technical regulation under Article 2.2 of the TBT Agreement involves in the first instance a relational analysis of three 
factors:

i. the degree of contribution made by the measure to the legitimate objective at issue;

ii. the trade-restrictiveness of the measure; and

iii. the nature of the risks at issue and the gravity of consequences that would arise from non-fulfilment of the objective(s) pursued by the Member through the measure. (1)

Furthermore, by applying the relational analysis specifically to the Australian plain packaging measures, the Panel concluded they are trade-restrictive (1, par. 7.1725). However, they do not violate Article 2.2 of the TBT Agreement because of their contribution to a legitimate objective and the alternative measures suggested by the complainants are not equivalent substitutes to them, considering the risks and consequences of the objective's non-fulfilment, as better detailed below.

From the outset, the Panel stated the objective of Australia's plain packaging was to "improve public health by reducing the use of, and exposure to, tobacco products" and also the "protection of human health or safety" was already an explicit legitimate objective contained in Article 2.2 (1, pars. 7.232, 7.243, 7.248 and 7.251). Additionally, it was not necessary to examine whether the implementation of certain obligations under the WHO FCTC constituted per se "a separate 'legitimate objective' independently of Australia's public health objective" (1, par. 7.244).

As stated previously, after assessing the external reviews of the existing scientific literature and all evidence available at the time of the decision, the Panel acknowledged that plain packaging, in combination with other tobacco-control measures maintained by Australia, contributed to Australia's objective of reducing the use of, and exposure to tobacco products.

Moreover, for a technical regulation to characterize a "trade-restrictiveness" within the meaning of Article 2.2, it must have a limiting effect on international trade. This is not necessarily dependent on the existence of discriminatory treatment of imported products (e.g. de jure discrimination). It may vary in each case and be based on qualitative or quantitative arguments and evidence relating to the characteristics of the challenged measures as revealed by their design and operation. For instance, a trade-restrictive technical regulation may involve "the value or other importance of imports in respect of the importing and/or exporting Members concerned, as well as both import-enhancing and import-reducing effects on the trade of other Members" (1, pars. 7.1072, 7.1073, 7.1074, 7.1076 and 7.1088).

In light of these criteria, the Panel reputed the Australian plain packaging measures to 
be "trade-restrictive, insofar as, by reducing the use of tobacco products, they reduce the volume of imported tobacco products on the Australian market, and thereby have a limiting effect' on trade" (1). By the way, it was made clear that the trade-restrictiveness of plain packaging measures was a consectary of their own objectives as explained before (1, pars. 7.1204, 7.1207 and 7.1208).

In spite of that, owing to lack of evidence, the Panel rejected there would be a "traderestrictiveness" by virtue of either a "downtrading" ${ }^{2}$, an increase in price competition followed by a fall in prices and a decrease in sales value of tobacco products and total value of imports, or higher costs associated with compliance with the new regulatory requirements (1, pars. 7.1197, 7.1214, 7.1215, 7.1244 and 7.1255).

Lastly, as an examination of the third factor within the "relational analysis", the Panel compared the challenged measures with possible alternative measures suggested by the complainants in light of the nature of the risks at issue and the gravity of the consequences that would arise from non-fulfilment of the legitimate objective, namely the protection of public health. The conclusion was none of them would be equivalent substitutes to plain packaging measures. In principle, some of them could be only complements that meaningfully contribute for the achievement of Australia's objective of improving public health by reducing the use of, and exposure to tobacco products (1, pars. 7.1417, 7.1464, 7.1453, 7.1470, 7.1531, 7.1545, 7.1584, 7.1615, 7.1624, 7.1685, 7.1716 and 7.1726). There were four suggestions of alternative measures (1, pars. 7.1392, 7.1472, 7.1546): an increase in the minimum legal purchasing age (MLPA) from 18 to 21 years, an increase in the taxation of tobacco products, social marketing campaigns and a pre-vetting mechanism (i.e. individualized assessment of packaging and sticks to ensure that they do not include any allegedly problematic design features). The risks amounted to public health not being improved as the use of, and exposure to tobacco products could not be reduced in the same manner, e.g. the number of smokers remain unchanged or even grow (1, pars. 7.1296 and 7.1297). The gravity of the consequences analyzed were addiction and mortality caused by tobacco, "the only legal consumer product that kills half of its long-term users when used exactly as intended by the manufacturer", besides other "extensive health, social, environmental, and economic consequences of tobacco consumption and exposure" (1, pars. 7.1298 and 7.1304).

8 Downtrading refers to a downward substitution to non-premium products. 


\title{
Panel decision on Article 20 of TRIPS Agreement (restrictions to trademarks)
}

The WTO Panel Reports acknowledged the Australia's tobacco plain packaging scheme configured "special requirements" that encumbered the use of trademarks in the course of trade (1, pars. 7.2241-7.2245, 7.2263, 7.2293 and 7.2606); however, they also accepted the contested measure to be "justifiable" and therefore there were no inconsistencies with Australia's obligations under Article 20 of the TRIPS Agreement (19):

\begin{abstract}
Article 20
Other Requirements

The use of a trademark in the course of trade shall not be unjustifiably encumbered by special requirements, such as use with another trademark, use in a special form or use in a manner detrimental to its capability to distinguish the goods or services of one undertaking from those of other undertakings. (19)
\end{abstract}

The Panel asserted unjustifiablity, as used in Article 20, connotes a situation where the use of a trademark is encumbered by special requirements in a manner that lacks a justification or reason that is sufficient to support the resulting encumbrance" (1, par. 7.2395). Due to the fact that the referred norm does not "expressly identify the types of reason that may form the basis for the 'justifiability' of an encumbrance" (Panel Reports), it looked for "general guidance in this respect in the context provided by other provisions of the TRIPS Agreement" (1), more precisely in Articles 7 and 8:

7.2403. Article 7 reflects the intention of establishing and maintaining a balance between the societal objectives mentioned therein. Article 8.1, for its part, makes clear that the provisions of the TRIPS Agreement are not intended to prevent the adoption, by Members, of laws and regulations pursuing certain legitimate objectives, specifically, measures 'necessary to protect public health and nutrition' and 'promote the public interest in sectors of vital importance to their socio-economic and technological development', provided that such measures are consistent with the provisions of the Agreement.

7.2404. Article 8 offers, in our view, useful contextual guidance for the interpretation of the term 'unjustifiably' in Article 20. Specifically, the principles reflected in Article 8.1 express the intention of drafters of the TRIPS Agreement to preserve the ability for WTO Members to pursue certain legitimate societal interests, at the same time as it confirms their recognition that certain measures adopted by WTO Members for such purposes may have an impact on IP rights, and requires that such measures be 'consistent with the provisions of the TRIPS Agreement'. (1)

This approach was based on Article 31 of the Vienna Convention on the Law of the Treaties (20), which prescribes a treaty shall be interpreted "in their context and in the light of its object and purpose" (Vienna Convention) comprising also "any subsequent agreement 
between the parties regarding the interpretation of the treaty or the application of its provisions" (Vienna Convention). In this respect, the Doha Declaration adopted by consensus in 2001 during the Fourth Ministerial Conference of the WTO reaffirmed such a rule of interpretation and therefore it would confirm that Articles 7 and 8 of the TRIPS Agreement provided an important context for the interpretation of Article 20 (1, pars. 7.2407-7.2411).

On the same grounds, the Panel found Article 17 provided as well "relevant context for the interpretation of Article 20, insofar as it can inform our understanding of the nature and extent of relevant interests of trademark owners that are recognized as 'legitimate' by the TRIPS Agreement” (1, par. 7.2427).

As a result, for determining whether the use of a trademark in the course of trade is being "unjustifiably" encumbered by special requirements and a violation of Article 20 of the TRIPS Agreement is ongoing, the Panel deployed a standard of review that should be carried out on a case-by-case basis (1, pars. 7.2430 and 7.2431). The proposed method would analyze the following factors in light of the particular circumstances of each case, but the Panel did not describe how exactly the different interests at issue should be "weighed and balanced":

a. the nature and extent of the encumbrance resulting from the special requirements, bearing in mind the legitimate interest of the trademark owner in using its trademark in the course of trade and thereby allowing the trademark to fulfil its intended function;

b. the reasons for which the special requirements are applied, including any societal interests they are intended to safeguard; and

c. whether these reasons provide sufficient support for the resulting encumbrance. (1)

By applying the above standard of review to the Australian plain packaging scheme, the Panel concluded Australia acted within the limits established by Article 20 of TRIPS Agreement, as it will be better detailed below.

Allowing trademarks only in the form prescribed by the legislation and regulations was certainly far-reaching in terms of the trademark owner's expected possibilities to extract economic value from the use of such features. Notwithstanding, the WTO Panel Reports (1) pronounced the tobacco manufacturers could still "use word trademarks, including brand and variant names, to distinguish their products from each other" and the complainant States have not demonstrated that consumers were unable to distinguish tobacco products of one undertaking from the other due to the encumbrances caused by the standardization of tobacco packets (1, par. 7.2570). Similarly, the allegations of increased price competition and 
adversely impact in particular premium brands (downtrading) were not duly proven (1, pars. 7.2572 and 7.2573).

In relation to the reasons for which the "special requirements" under the Australian plain packaging scheme are applied, including the societal interests they are intended to safeguard, the WTO Panel Reports sustained the improvement of public health by controlling tobacco products, as explained by Australia, formed sufficient support for the resulting encumbrances on the use of trademarks:

7.2587. We note that the parties are in agreement about the importance of public health as a policy concern. They, furthermore, agree on the importance of effective tobacco control measures to reduce the public health burden resulting from tobacco use. We also recall that the Appellate Body has recognized the preservation of human life and health as a value that is 'both vital and important in the highest degree'.

7.2588. As regards the TRIPS Agreement in particular, we noted earlier that its Article 8.1 sheds light on the types of societal interests that may provide a basis for the justification of measures under the specific terms of Article 20, and expressly recognizes public health as such a societal interest. Paragraph 5 of the Doha Declaration invites us to read 'each provision of the TRIPS Agreement' in the light of the object and purpose of the Agreement, as expressed in particular in its objectives and principles, which includes Article 8. WTO Members have further emphasized the importance of public health as a legitimate policy concern in paragraph 4 of the Doha Declaration. (1)

Finally, as previously stated, in light of the evidence produced, the WTO Panel Reports considered that plain packaging should be understood in combination with all other measures already maintained by Australia. Together, they are capable of contributing, and do in fact contribute, to Australia's objective of improving public health by reducing the use of, and exposure to tobacco products. Thus, this suggests the reasons for which these "special requirements" (plain packaging rules) are applied provide sufficient support for the application of the resulting encumbrances on the use of trademarks. The Panel remarked the interpretation of plain packaging as the integrator of a broader public health policy that effectively combines different measures to achieve its objectives is in line with the existing WHO FCTC:

7.2589. We further note Australia's explanation that the decision to introduce the TPP measures was made in the context of a comprehensive range of tobacco control measures, including advertising and promotional bans, excise taxes, GHWs, and investments in anti-smoking initiatives. We also note the reference made, in the TPP Act and its Explanatory Memorandum, to Australia's intention of giving effect to certain obligations under the FCTC through the adoption of the TPP measures, as well as Australia's explanations 
of how the TPP measures reflect the Article 11 and Article 13 FCTC Guidelines. As regards the public health objectives of the FCTC, we note that the preamble of the FCTC recognizes that 'the spread of the tobacco epidemic is a global problem with serious consequences for public health that calls for the widest possible international cooperation and the participation of all countries in an effective, appropriate and comprehensive international response'.

[...]

7.2595. We recall that the Article 11 FCTC Guidelines provide that the Parties to the FCTC 'should consider adopting measures to restrict or prohibit the use of logos, colours, brand images or promotional information on packaging other than brand names and product names displayed in a standard colour and font style (plain packaging)'. Similarly, the Article 13 FCTC Guidelines recommend that the Parties to the FCTC 'consider adopting plain packaging requirements to eliminate the effects of advertising or promotion on packaging'. The Guidelines elaborate on the standard features of plain packaging as including nothing other than a brand or product name, without any logos or other features, in a prescribed font style and size.

7.2596. We note the reference made in the TPP Act and its Explanatory Memorandum to Australia's intention of giving effect to certain obligations under the FCTC through the adoption of the TPP measures. In our view, the importance of the public health reasons for which the trademark-related special requirements under the TPP measures are applied is further underscored by the fact that Australia pursues its domestic public health objective in line with its commitments under the FCTC, which 'was developed in response to the globalization of the tobacco epidemic' and has been ratified by 180 countries. (1)

Based on the legal reasoning explained above, the WTO decision rejected the alleged violations of Article 2.2 of the TBT Agreement and Article 20 of TRIPS Agreement (1). A final ruling is still pending, but so far the referred decision could foster the development of public health policies supported by the WHO FCTC regarding the adoption of plain packaging.

\section{Conclusion}

The complexity of the modern society echoes in the overlapping legal protection of certain values through different sets of rules, domestically and internationally, which also have different social and economic dimensions and yet need to be interpreted and applied in a way that solves apparent conflicts of laws and settle a vast number of litigious cases.

The recent adoption by the WTO DSB of the Panel Reports that resolved the disputes initiated by Cuba, Dominican Republic, Honduras and Indonesia against the Australia's tobacco plain package scheme clarified that plain packages do not represent technical barriers under TBT Agreement nor restrictions to trademarks under TRIPS Agreement. This WTO decision also reverberated in the applicability of the WHO FCTC, whose guidelines 
established in the COP propose the adoption of plain packaging among other policy recommendations as best practices and standards to help governments in the treatyimplementation process, though the treaty itself does not impose this obligation.

From a microeconomic policy analysis, the standardization of the tobacco packets is a reasonable regulatory approach at a government's disposal for addressing welfare losses due to externalities and internalities. Taking into account the rules orienting the burden of proof and notwithstanding the methodological difficulties in assessing exclusively the actual impact of plain packaging measures on each possible consumer behavior, the overall conclusions of the WTO Panel Reports about the effects of the standardization of tobacco packets still favored Australia's position. The Panel emphasized that the comprehension of plain packaging measures should be found in a broader policy context, which is also in concordance with WHO FCTC. Thus, in combination with other tobacco-control measures kept by Australia and examining the existing empirical evidence, plain packaging contributed for reducing the use of, and exposure to tobacco products and this would in turn undeniably have an impact on smoking behaviors. This had an important role in the decision under analysis, notably with respect to Article 2.2 of the TBT Agreement and Article 20 of the TRIPS Agreement.

By applying the relational analysis to the Australian plain packaging measures, the Panel concluded they are trade-restrictive. However, they do not violate Article 2.2 of the TBT Agreement because of their contribution to a legitimate objective and the alternative measures suggested by the complainants are not equivalent substitutes to them, considering the risks and consequences of the objective's non-fulfilment.

Similarly, the standard of review revealed the Australian plain packaging measures are justifiable encumbrances to trademarks within the limits established by Article 20 of TRIPS Agreement, considering the societal interests they are intended to safeguard.

Although Honduras and Dominican Republic have appealed and consequently a final ruling is still pending, the abovementioned WTO Panel Reports dispelled many of the doubts raised in the international scenario concerning the pioneering implementation by Australia of tobacco plain packaging. Indeed, the upholding of such understanding under WTO law may contribute in the coming years towards a worldwide employment of similar policies in an increasing number of countries whose improvements in domestic policymaking regarding tobacco control and health protection sometimes might simply not occur due to the inaccurate 
belief in non-existent inconsistencies with their multiple international obligations. Nevertheless, this is just a hypothesis, and only the future will confirm or reject it.

In spite of some criticisms (12), the ruling is a recognition under WTO law of a State's regulatory autonomy to choose plain packaging as a legitimate policy measure based on evidence to protect public health.

\section{References}

1. World Trade Organization. Panel Reports, Australia - Certain Measures Concerning Trademarks, Geographical Indications and Other Plain Packaging Requirements Applicable to Tobacco Products and Packaging. Disponível em:

https://www.wto.org/english/tratop_e/dispu_e/cases_e/ds467_e.htm. Acesso em: 14 mar. 2020

2. World Health Organization. Tobacco plain packaging: global status update. 2018. Disponível em: https://ideas.repec.org/p/cdl/ctcres/qt5kg1j3w9.html. Acesso em: 14 mar. 2020.

3. Voon T. Third strike: The WTO panel reports upholding Australia's tobacco plain packaging scheme. The Journal of World Investment \& Trade. 2019 Feb 11;20(1):146-184.

4. Van der Bossche P, Zdouc W. The Law and Policy of the World Trade Organization. 3rd ed. Cambridge: Cambridge University Press, 2013.

5. Rules DS. Understanding on rules and procedures governing the settlement of disputes. Marrakesh Agreement Establishing the World Trade Organization, Annex. 1994;2:1869. Disponível em: https://www.wto.org/english/tratop_e/dispu_e/dsu_e.htm. Acesso em: 14 mar. 2020

6. World Health Organization. Tobacco fact sheet. 2019. Disponível em:

https://www.who.int/news-room/fact-sheets/detail/tobacco. Acesso em: 14 mar. 2020.

7. World Health Organization. WHO Framework Convention on Tobacco Control: Guidelines for Implementation of Article 5. 3, Articles 8 to 14. 2013. Disponível em: https://www.who.int/fctc/treaty_instruments/adopted/guidel_2011/en/. Acesso em: 14 mar. 2020

8. World Health Organization. Plain packaging of tobacco products: evidence, design and implementation. 2016. Disponível em:

https://www.who.int/tobacco/publications/industry/plain-packaging-tobacco-products/en/. Acesso em: 14 mar. 2020

9. Frankel S, Gervais D. Plain Packaging and the Interpretation of the TRIPS Agreement. Vand. J. Transnat'I L. 2013;46:1149. Disponível em: https://heinonline.org/HOL/LandingPage?handle=hein.journals/vantl46\&div=36\&id=\&page= Acesso em: 14 mar. 2020 
10. World Health Organization. WHO Framework Convention on Tobacco Control.

Disponível em: https://apps.who.int/iris/bitstream/handle/10665/206081/B3677.pdf. Acesso em: 14 mar. 2020

11. Gruber J. Public Finance and Public Policy. 3rd ed. New York: Worth Publishers, 2011.

12. Maxwell A. Plainly Justifiable: The World Trade Organization's Ruling on the Validity of Australia's Plain Packaging under Article 20 of the Trips Agreement. Asian J. WTO \& Int'I Health L \& Pol'y. 2019;14:115. Disponível em:

https://heinonline.org/HOL/LandingPage?handle=hein.journals/aihlp14\&div=7\&id=\&page= Acesso em: 14 mar. 2020

13. Mirzabegian S. Big Tobacco v Australia: Challenges to Plain Packaging. Business and Human Rights Journal. 2019 Jan;4(1):177-84.

14. Holden $C$, Hawkins B. Trade and investment agreements and the global politics of health. In: The Oxford Handbook of Global Health Politics; 2018 Jan 18.

15. Evans MD. International Law. 2nd ed. Oxford University Press, 2006. 833 p.

16. Ruse-Khan HG. A Conflict-of-Laws Approach to Competing Rationalities in International Law: The Case of Plain Packaging Between Intellectual Property, Trade, Investment and Health. Journal of Private International Law. 2013 Aug 21;9(2):309-48.

17. World Trade Organization. One-page summary of key findings of this dispute. 2018 Disponível em:

https://www.wto.org/english/tratop_e/dispu_e/cases_e/1pagesum_e/ds467sum_e.pdf. Acesso em: 14 mar. 2020.

18. World Trade Organization. Uruguay Round Agreement. Agreement on Technical Barriers to Trade. Disponível em: https://www.wto.org/english/docs_e/legal_e/17-tbt_e.htm. Acesso em: 14 mar. 2020.

19. World Trade Organization. Agreement On Trade-Related Aspects Of Intellectual Property Rights. 15 April 1994. Disponível em: https://www.wto.org/english/docs_e/legal_e/27-trips.pdf Acesso em: 14 mar. 2020.

20. United Nations. Vienna Convention on the Law of Treaties. 23 May 1969 Disponível em: https://treaties.un.org/doc/Publication/UNTS/Volume\%201155/volume-1155-I-18232English.pdf. Acesso em: 14 mar. 2020. 


\section{Como citar este artigo:}

Submetido em: 01/09/19

Soares Junior WC. The plain packaging of tobacco products and its recognition by the WTO as a legitimate policy measure for the protection of public health. Cadernos Ibero-Americanos de Direito Sanitário. 2020 abr./jun.; 9(2): 29-53.

http://dx.doi.org/10.17566/ciads.v9i2.581 